\title{
Immobilization of Toxic Metals and Radionuclides in Porous and Fractured Media: Optimizing Biogeochemical Reduction versus Geochemical Oxidation
}

\author{
Oak Ridge National Laboratory \\ September 1997
}

\section{Progress Report}

\section{Principal Investigator}

Philip M. Jardine

(423) 574-8058 (Phone)

(423) 576-8646 (Fax)

ipj@ornl.gov

Oak Ridge National Laboratory

P.O. Box 2008, MS 6038

Oak Ridge, Tennessee 3783 1-6038

\section{Co-Investigators}

Scott C. Brooks

(423) 574-6398 (Phone)

(423) 574-8646 (Fax)

3sb@ornl.gov

Oak Ridge National Laboratory

P.O. Box 2008, MS 6038

Oak Ridge, Tennessee 3783 1-6038

Tommy J. Phelps

(423) 574-7290 (Phone)

(423) 576-8543 (Fax)

tkp@ornl.gov

Oak Ridge National Laboratory

P.O. Box 2008, MS 6036

Oak Ridge, Tennessee 3783 1-6036

Scott E. Fendorf

(208) 885-6767 (Phone)

(208) 885-7760 (Fax)

sfendorf@uidaho.edu

University of Idaho

Moscow, ID 83844-2339
James E. Saiers

(305) 348-3117 (Phone)

(305) 348-3877 (Fax)

saiers@fiu.edu

Florida International University

Miami, FL 33199

John Zachara

(509) 375-2993 (Phone)

(509) 375-2718 (Fax)

jm_zachara@pnl.gov

Battelle Pacific Northwest Nat'1 Laboratory

Battelle Boulevard

Richland, Washington 99352 


\section{Research Objectives}

The purpose of our research is to provide an improved understanding and predictive capability of the mechanisms that allow metal-reducing bacteria to be effective in the bioremediation of subsurface environments contaminated with toxic metals and radionuclides. The research findings of the work plan will (1) provide new insights into the previously unexplored areas of competing geochemical and microbiological oxidation/reduction reactions that govern the fate and transport of redox sensitive contaminants in subsurface environments and (2) provide basic knowledge to define the optimum conditions for the microbial reduction and concomitant immobilization of toxic metals and radionuclides in the subsurface. Strategies that use in situ contaminant immobilization can be efficient and cost-effective remediation options. This project will focus on the following specific objectives.

- Develop an improved understanding of the rates and mechanisms of competing geochemical and microbiological oxidation/reduction reactions that govern the fate and transport of uranium (U), chromium (Cr), and cobalt-EDTA (Co-EDTA) in the subsurface.

- Quantify the conditions that optimize the microbial reduction of toxic metals and radionuclides for the purpose of contaminant containment and remediation in heterogeneous systems that have competing geochemical oxidation, sorption, and organic ligands.

\section{Research Statement}

The disposal of toxic metals and radioactive wastes generated at U.S. Department of Energy (DOE) facilities has historically involved shallow land burial via pits, trenches, and cribs. Much of this waste is ill-defined mixtures of metals, radionuclides, and organics that have migrated into the surrounding soils and groundwater. Of particular concern are the redox sensitive radionuclides ${ }^{238.235} \mathrm{U}$ and ${ }^{60} \mathrm{Co}$, and the redox sensitive metal $\mathrm{Cr}$. These contaminants can exist in more than one oxidation state, and their behavior in the environment depends on their oxidation states. For example, hexavalent chromium $(\mathrm{Cr}(\mathrm{VI}))$ has a high solubility and is mobile in the environment. It is also subject to biological uptake and is highly toxic. In contrast, the reduced form of chromium, $\mathrm{Cr}(\mathrm{III})$, has a much lower solubility, and, therefore, is less mobile in the environment.

In an effort to control the off-site migration of these priority pollutants, research within this project is using metal-reducing bacteria to stabilize contaminant plumes in the subsurface. Our challenge is to optimize microbial reduction processes in the presence of competing geochemical oxidation and sorption reactions and to sustain microbial reduction processes in situ for long periods of time.

- There are significant deficiencies in our knowledge base regarding implementation of successful microbial reduction strategies in situ. Specifically, experiments involving contaminant reduction in the presence of solid phase minerals are extremely rare. Further, studies are frequently conducted using static, batch methods that complicate the interpretation of results because these are closed systems. Our research uses a dynamic flow technique to quantify the geochemical oxidation and microbial reduction rates and mechanisms 
controlling the mobility of $\mathrm{U}, \mathrm{Cr}$, and Co-EDTA in pure and in heterogeneous media. This information is imperative to the successful application of microbially mediated contaminant containment in the field.

- Macroscopic observations of contaminant fate and transport are seldom substantiated with definitive microscopic scale information. This often results in the speculative interpretation and the empirical description of the observed data. Our research combines the use of novel spectroscopic techniques with macroscopic flow and transport experiments to monitor the time-dependent redox transformation and immobilization of $\mathrm{U}, \mathrm{Cr}$, and Co-EDTA by subsurface media. X-ray absorption spectroscopy (XAS), located at the Stanford Synchrotron Radiation Laboratory, is used to probe for contaminants within soils and sediments, permitting the determination of the contaminant chemical and structural state (e.g. redox states and surface binding mechanisms). This information is imperative to the development of mechanistic models that are better equipped to assess the waste migration problems of DOE and the U.S. Department of Defense (DOD).

- Numerical codes that couple multiple physical, chemical, and biological processes often compromise conceptual rigor for simplicity and efficient execution. By-compromising the conceptual model, our ability to scale parameters to the field becomes limited and remedial strategies often rely solely on empirical approaches. Our research is developing a conceptually rigorous numerical model that couples time-dependent hydrologicbiogeochemical processes for simulating our experimental data. The calibrated code will be an attractive item for assessing contaminant migration and remedial strategy needs within DOE's and DOD's waste management programs.

\section{Research Progress}

\section{Chromium System}

- Investigators from Oak Ridge National Laboratory (ORNL), the University of Idaho, and Florida International University (FIU) have quantified the fate and transport of $\mathrm{Cr}$ (III) and Cr(VI) through Savannah River, Hanford, and ORNL, soils and sediments. Investigations emphasized the effects of redox and interfacial geochemical processes on the time-dependent mobility of $\mathrm{Cr}$ in the subsurface media.

$\mathrm{Cr}$ (III) transport through the Savannah River soil (McBean formation at a 147-ft depth near the Old Burial Ground site) and the ORNL soil involves multispecies, time-dependent sorption reactions with a small percentage of the $\mathrm{Cr}$ (III) being oxidized to $\mathrm{Cr}$ (VI). The lack of oxidation to $\mathrm{Cr}(\mathrm{VI})$ is encouraging because the oxidized species is highly mobile and significantly more toxic than $\mathrm{Cr}$ (III). The soils have a tremendous capacity to sorb $\mathrm{Cr}$ (III) and this significantly delays its mobility in the subsurface. In contrast, $\mathrm{Cr}$ (III) transport through Hanford sediments is characterized by significant oxidation of $\mathrm{Cr}(\mathrm{III})$ to $\mathrm{Cr}(\mathrm{VI})$, with the redox reaction being time-dependent and independent of $\mathrm{pH}$. It appears that soil $\mathrm{Mn}$ oxides are catalyzing the oxidation of $\mathrm{Cr}(\mathrm{III})$ to $\mathrm{Cr}(\mathrm{VI})$ in the Hanford sediments. 
$\mathrm{Cr}(\mathrm{VI})$ transport through the Savannah River soil and the ORNL soil also involves sorption and significant reduction to $\mathrm{Cr}(\mathrm{III})$. The capacity of the soil to sorb $\mathrm{Cr}(\mathrm{VI})$ is about 50 times less than that for $\mathrm{Cr}(\mathrm{III})$, thus allowing $\mathrm{Cr}(\mathrm{VI})$ to be highly mobile. The mobility of $\mathrm{Cr}(\mathrm{VI})$ is most significant at higher $\mathrm{pH}$ conditions because $\mathrm{Cr}(\mathrm{VI})$ sorption decreases dramatically with increasing $\mathrm{pH}$. Fortunately, our research group has discovered that as much as $40 \%$ of the $\mathrm{Cr}(\mathrm{VI})$ is reduced to the more reactive $\mathrm{Cr}(\mathrm{III})$ during transport. The amount of reduction is dependent on the residence time of the $\mathrm{Cr}(\mathrm{VI})$ in the soil and the organic carbon content. The use of natural organic carbon appears to be an attractive remedial strategy for immobilizing $\mathrm{Cr}$ in subsurface environments. Experiments are also being designed to accelerate the reduction of $\mathrm{Cr}(\mathrm{VI})$ to $\mathrm{Cr}(\mathrm{III})$ using metal-reducing bacteria.

- University of Idaho and ORNL investigators used XAS at the Stanford Synchrotron Radiation Laboratory to confirm dynamic redox changes and sorption mechanisms of $\mathrm{Cr}(\mathrm{III})$ and $\mathrm{Cr}(\mathrm{VI})$ on Savannah River, ORNL, and Hanford soils as a function of $\mathrm{pH}$ and dynamic flow conditions;

Using a dynamic flow technique, the time-dependent reduction of $\mathrm{Cr}(\mathrm{VI})$ to $\mathrm{Cr}(\mathrm{III})$ by Savannah River and ORNL soils was quantified using XAS. The microscopic investigations were consistent with macroscopic flow and transport experiments described above and suggested that the formation of $\mathrm{Cr}$ (III) enhanced $\mathrm{Cr}$ stabilization in the subsurface by nearly 25 fold. Results from XAS definivitely showed that $\mathrm{Cr}$ (III) was bound to the soil surface via inner-sphere complexes coupled with a $\mathrm{Cr}$ (III)-hydroxide phase. We also observed that regardless of whether $\mathrm{Cr}(\mathrm{VI})$ or $\mathrm{Cr}(\mathrm{III})$ was introduced onto the soils, the solid-phase $\mathrm{Cr}$ species were dominated by $\mathrm{Cr}$ (III). Changes in solid-phase speciation relative to the influent solutions were dependent on the composition of the soils. Those containing organic material (ORNL) enhanced $\mathrm{Cr}(\mathrm{VI})$ reduction to $\mathrm{Cr}(\mathrm{III})$, with the latter then adsorbing or precipitating on the soil solids. In contrast, soils containing Mn oxides (Hanford) favored oxidation of $\mathrm{Cr}(\mathrm{IlI})$ to $\mathrm{Cr}(\mathrm{VI})$; however, $\mathrm{Cr}(\mathrm{VI})$ was partitioned to the solution phase and did not accumulate on the solids even though oxidation was favored. These studies are the first documented use of XAS for providing novel insights into the geochemical reactions of the toxic element $\mathrm{Cr}$ with soil under conditions of hydrodynamic flow.

\section{Cobalt-EDTA System}

- Investigators from ORNL and the University of Idaho have quantified the fate and transport of Co(II)EDTA and Co(III)EDTA in ORNL soils and in minerals common to soils. Investigations emphasized the effects of geochemical oxidation and biological reduction processes on the time-dependent mobility of Co-EDTA in the subsurface media.

The transport of Co(II)EDTA through ORNL soils was characterized by a Mn-oxide-induced oxidation of the cocontaminant to form Co(III)EDTA. Both species were sorbed by the solid phase, with the sorption process being independent of ionic strength. The environmental implications concerning the oxidation of Co(II)EDTA to Co(III)EDTA are pronounced because the oxidation product, $\mathrm{Co}(\mathrm{III}) \mathrm{EDTA}$, is extremely stable $(\log \mathrm{K}=40)$, and this enhances its persistence and transport in subsurface environments. 
Research by our group has demonstrated that both Mn and Fe oxides, common to most soils and sediments, can catalyze the oxidation of Co(II)EDTA to Co(III)EDTA. The magnitude of the oxidation reaction decreases with time, and XAS analysis at the Stanford Synchrotron Radiation Laboratory confirmed that certain Mn-oxide reduction products can slowly poison the oxidation reaction, particularly under anoxic conditions.

In an effort to convert Co(III)EDTA to the less stable, more desirable Co(II)EDTA species, metal-reducing bacteria, Shewanella alga, strain BrY, are being used to reduce Co(III)EDTA to $\mathrm{Co}$ (II)EDTA. Bacterial reduction of $\mathrm{Co}$ (III)EDTA is rapid and approximately first-order with respect to cell number, with time scales on the order of minutes. Under no-growth conditions, there is a rapid loss in metal-reducing activity suggesting that the bacteria must be actively growing to be effective as an in situ remedial strategy. Our group has demonstrated for the first time the sustained bacterial reduction of Co(III)EDTA to Co(II)EDTA under growth conditions in a dynamic flow field. By keeping the bacteria healthy and growing, we were able to effectively stabilize Co(II)EDTA in a flowing subsurface system. This is advantageous from a remedial perspective because Co(II)EDTA is a weaker complex relative to Co(III)EDTA and, therefore, is easier to remediate. These findings are currently being extended to systems that offer the unfortunate circumstance of competing geochemical oxidation reactions.

\section{Uranium System}

1 Investigators from ORNL are quantifying the fate and transport of U(IV) and U(VI) in ORNL, Hanford, and Savannah River soils and sediments. Investigations are emphasizing the effects of geochemical oxidation and interfacial sorption reactions and the effects of biological reduction processes on the time-dependent mobility of $U$ in the subsurface media.

The sorption of U(VI) by ORNL soils is extensive and highly $\mathrm{pH}$ dependent. In open systems, $\mathrm{U}(\mathrm{VI})$ sorption is characterized by a sharp increase in sorption near $\mathrm{pH} 5$, followed by a sharp decrease in sorption near $\mathrm{pH}$ 6.5. Increased sorption is the result of an increase of negatively charged sites on the solid phase as the $\mathrm{pH}$ rises, and the decrease in sorption is the result of neutral U-carbonate complexes forming at $\mathrm{pH}$ values above 6.5. Thus, for conditions below $\mathrm{pH} 5$ and above $\mathrm{pH} 6.5, \mathrm{U}(\mathrm{VI})$ is extremely mobile in subsurface systems similar to those at ORNL, which contain appreciable Fe-oxide coated clays.

In an effort to convert U(VI) to the less soluble, more desirable U(IV) species, metal-reducing bacteria, Shewanella alga, strain BrY, are being used to reduce U(VI) to U(IV). Bacterial reduction of $\mathrm{U}(\mathrm{VI})$ is rapid, with time scales on the order of minutes to hours, and is strongly dependent on cell number. As in the Co system, for conditions of no-growth, there is a rapid loss in metal reducing activity suggesting that the bacteria must be actively growing to be effective as an in situ remedial strategy. These findings are currently being extended to dynamic flowing systems, both in the presence and absence of competing geochemical oxidation reactions. 
Beam time has been secured at the Stanford Synchrotron Radiation Laboratory for November 1997 and throughout FY 1998 and FY 1999 so that time-resolved U redox and interfacial sorption processes can be quantified at the molecular scale.

\section{Modeling}

- The macroscopic and microscopic experimental observations described above are being merged by FIU for the purpose of parameterizing a newly developed multicomponent, multispecies numerical code. The model is used to simulate toxic metal and radionuclide transport in the presence of competing microbial reduction reactions and geochemical oxidation reactions. It will be a valuable tool for determining the conditions that optimize the microbial reduction of toxic metals and radionuclides, for the purpose of contaminant containment and remediation in heterogeneous subsurface environments.

FIU has completed phase one in the development of the multicomponent, multispecies numerical code that will be used to simulate contaminant transport. The code describes a variety of geochemical processes and bioreduction, and it is fully kinetic. Experimental data described above has been sent to FIU, and simulations have been initiated. Mechanistic information obtained from XAS will also be forwarded when the data have been fully interpreted. This will help with the numerical details that are necessary for building a conceptually correct simulation code.

\section{Summary of Accomplishments}

- New insights on the geochemical processes that influence the fate and transport of $\mathrm{Cr}$ in subsurface environments (abstract accepted and manuscript in preparation).

- New insights regarding the biogeochemical redox processes that influence the stabilization of Co-EDTA in subsurface environments (invited abstract accepted and manuscript in preparation).

- Using XAS at the Stanford Synchrotron Radiation Laboratory to confirm redox dynamics and sorption mechanisms within the $\mathrm{Cr}$ and Co-EDTA systems (invited abstract accepted, one invited manuscript submitted, and one manuscript in preparation).

- New insights regarding U(VI) bioreduction processes and sorption mechanisms on soil.

- Development of a multicomponent, multispecies numerical code that is being used to simulate the metal transport and bioreduction data described above. 


\section{Papers and Abstracts}

Brooks, S. C., and P. M. Jardine. 1997. "Bacterial Reduction of Toxic Metals During Dynamic Plow." Invited paper by American Society of Agronomy, Anaheim, Calif., October 26-31, 1997.

Brooks, S. C., S. L. Carroll, and P. M. Jardine. "Bacterial Reduction of Co(III)EDTA Under Batch and Dynamic Flow Conditions." To be submitted to Applied and Environmental Microbiology.

Fendorf, S. E., P. M. Jardine, and S. C. Brooks. "Redox Transformations and Sorption Mechanisms of Cr on Soil Using X-ray Absorption Spectroscopy." To be submitted to Environmental Science and Technology.

Fendorf, S. E., P. M. Jardine, and S. C. Brooks. 1997. "Sorption Induced Inhibition of Redox Reactions Involving Manganese Oxides." Invited paper by American Chemical Society, San Francisco, Calif., April 13-17, 1997.

Fendorf, S. E., P. M. Jardine, D. L. Taylor, and S. C. Brooks. 1997. "Auto-inhibition of Oxide Mineral Oxidative Capacity Toward Co(II)EDTA." Invited submission to D. L. Sparks and T. Grundel (eds.), Kinetics and Mechanisms of Sorption Processes at the Mineral- Water Interface, ACS Symposium Series.

Jardine, P. M., T. L. Mehlhom, S. C. Brooks, and S. E. Fendorf. "Geochemical Processes Governing the Fate and Transport of $\mathbf{C r}(\mathbf{I I})$ and $\mathbf{C r}(\mathrm{VI})$ in Soils and Sediments." To be submitted to Geochim. Cosmoschim. Acta.

Mehlhom, T. L., P. M. Jardine, S. C. Brooks, S. E. Fendorf, and J. E. Saiers. 1997. "Geochemical Processes Governing the Fate and Transport of $\mathrm{Cr}$ (III) and $\mathrm{Cr}$ (VI) in Soils." Paper accepted by American Society of Agronomy, Anaheim, Calif., October 26-31, 1997. 